\title{
Synthesis and Cytotoxicity Study of Some Acetylisatins and Diazobiphenyls
}

\author{
Mohammad Mamun Hossain*, Sukanta Kumar Shaha, Foysal Aziz, Rahat Khan \\ and Md. Mahabub Hossain \\ Department of Chemistry, Jahangirnagar University, Shaver, Dhaka-1342, Bangladesh
}

\begin{abstract}
Nitrogenous heterocyclic compounds, oxindoles especially isatins and related heterocyles have excellent antifungal, anti-inflammatory, antimicrobial and anticancer activities. Oxindoles keto lactams (1-3) were synthesized according to modified Sandmayer method and their $N$-acetylated compounds (4-6) gave diazo-biphenyls (7-10) through ring cleavage and consequent cyclization reaction. Bis-amide (11), and Schiff-base (12) were synthesized from oxindoles respectively. The investigation of cytotoxicity of the synthesized compounds was carried out against brine shrimp lethality bioassay. In our present investigation some of the synthesized compounds such as halogen substituted acetylisatins (4-6) and the ring extended diazo-biphenyls, (7-10) have been shown to exhibit strong cytotoxic effect.
\end{abstract}

Key words: diazo-biphenyls, oxindoles, cytotoxicity, brine shrimp

\section{INTRODUCTION}

The oxo-derivatives of indole particularly isatins and related compounds are important class of compounds due to their biological effects, including antifungal, antiviral, anticancer and antiproliferative activities. $^{1-2}$ These compounds are very useful synthetic intermediates and can function as suitable building blocks to synthesize some other biologically active compounds and other natural products. These compounds are of great interest in oncology, microbiology, and immunology. ${ }^{2}$ Hence a significant rising research interest in the design of different oxindoles and related compounds as drugs is currently observed in the field of medicinal chemistry. ${ }^{3}$ The Schiff-bases and spiro-thiadiazoline derivatives of isatins have shown remarkable biological activities. ${ }^{4-6}$ Although the oxindoles reported earlier due to their marked cytotoxicity, ${ }^{7-9}$ diazo-biphenyls are first time ever to screen for

Correspondence to:

Mohammad Mamun Hossain.

E-mail: chemmamun2@yahoo.com

Dhaka Univ. J. Pharm. Sci. 9(1): 1-6, 2010 (June) cytotoxicity. Accordingly numerous diazo-biphenyl compounds were synthesized from the reaction of isatins and ethylene/propylene diamine in fairly good yields.

\section{MATERIALS AND METHODS}

Substituted isatins 1-3 were synthesized from their respective oximinoacetanilide precursors according to the modified standard procedure. ${ }^{3}$ Oximinoacetanilides were heated with concentrated sulfuric acid and the progress of the reaction was monitored by TLC $\left(\mathrm{CH}_{2} \mathrm{Cl}_{2}\right.$ : EtOAc, 5:1). The reaction mixture was neutralized with $20 \% \mathrm{Na}_{2} \mathrm{CO}_{3}$ solution to give crystalline solids of compounds 1-3 separately in very high yields. Isatin were taken in a mixture of acetic anhydride and pyridine and the mixture was heated at $80^{\circ} \mathrm{C}$. The reaction mixture was cooled to room temperature and then kept under ice for $45 \mathrm{~min}$ followed by neutralization with $5 \%$ $\mathrm{Na}_{2} \mathrm{CO}_{3}$ solution. A deep violet crystalline solid was obtained, which was filtered off and washed with nhexane and dried under vacuum. Recrystallization of 
the crude solid from a mixture of $\mathrm{CHCl}_{3}$ and EtOAc gave $\mathbf{4}$ as a deep violet crystalline solid in good yield. Compounds 5 and $\mathbf{6}$ were also synthesized in a similar trend. $N$-Acetylisatin (4) was dissolved in ethanol followed by the addition of ethane-1,2diamine. The reaction mixture was refluxed for an hour. A deep violet crystalline solid was obtained on cooling. The crude solid was recrystallized from a mixture of EtOAc and hexane to give diazo-biphenyl compound 7 in moderate yield. Compounds 8-10 were also obtained in a similar manner as in the case of compound 7. A bis-amido compound $\mathbf{1 1}$ was synthesized by the treatment of $\mathbf{7}$ with ethanol and then 1,3-diamino propane at low temperature. A Schiff-base 12 was prepared from $N$-acetyl isatin 4 with $p$-chloroaniline.

Synthesized compounds
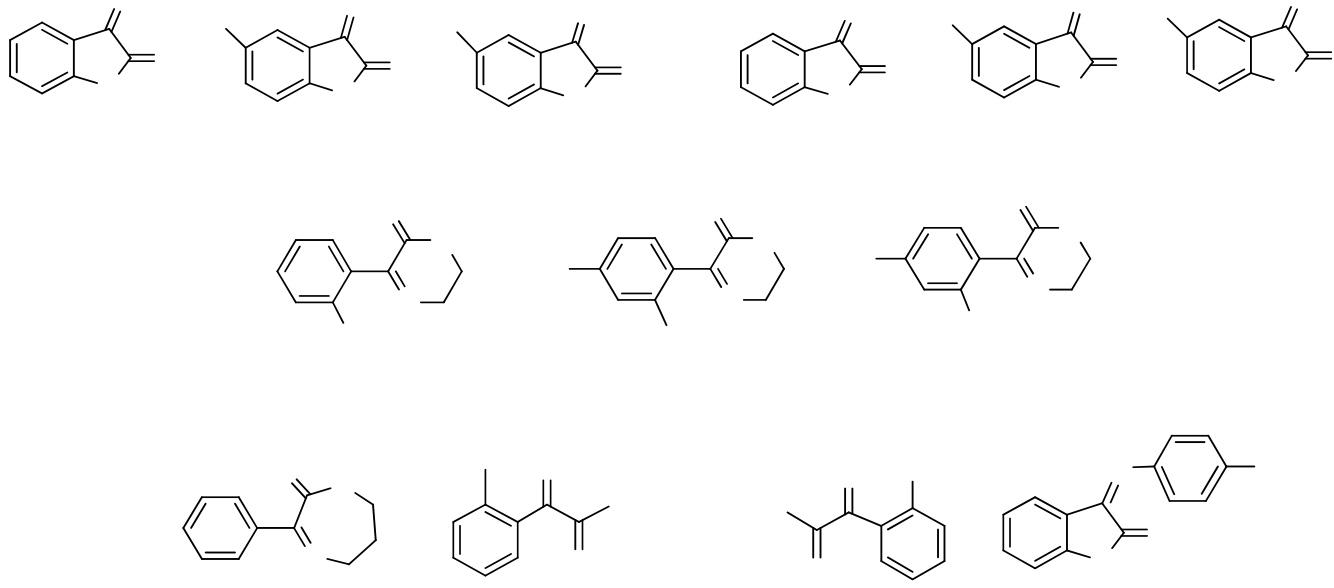

The structures of the synthe(ized compounds were characterized by physical methods such @isIR (FT Infra-red Spectrophotometer in $\mathrm{KBr}$ disc), ${ }^{1} \mathrm{H}$ NMR and ${ }^{13} \mathrm{C}$-NMR (WP-400 NMR speelrometer). The spectral data of compound $2 \mathrm{~d}$ is reported here while the compound $\mathbf{1}$ is known. $\mathrm{H}$

2: $\mathrm{IR}\left(\mathrm{KBr}, \mathrm{cm}^{-1}\right): 3450(\mathrm{~s}$ N-H, lactam ), 3031 (C-H, Ar), 1750 (s, C=O, lactam), $1728 \quad(\mathrm{~s}, \mathrm{C}=\mathrm{O}$, keto), $1608(\mathrm{C}=\mathrm{C}, \mathrm{Ar}) ;{ }^{1} \mathrm{H}-\mathrm{NMR}(\delta \mathrm{ppm})\left(\mathrm{CD}_{3} \mathrm{OD}\right)$ : $6.93\left(\mathrm{~d}, 1 \mathrm{H}, J_{\mathrm{m}}=1.7 \mathrm{~Hz}, \mathrm{ArH}, \mathrm{C}-4\right), 7.62(\mathrm{~m}, 2 \mathrm{H}, \mathrm{ArH}$, C-6, 7); ${ }^{13} \mathrm{C}-\mathrm{NMR}$ (סppm) $\left(\mathrm{CD}_{3} \mathrm{OD}\right): 187.69(\mathrm{O}=\mathrm{C})$, $159.57(\mathrm{O}=\mathrm{C}$, lactam $) ; 137.51,134.19,130.21$, $129.61,122.27 \& 118.98$ (aromatic carbons).

3: $\mathrm{IR}\left(\mathrm{KBr}, \mathrm{cm}^{-1}\right): 3361$ (s, N-H, lactam) 3059 (s, $\mathrm{C}-\mathrm{H}, \mathrm{Ar}), 1750$ (s, C=O, lactam), 1728 (s, C=O, keto), $1620(\mathrm{C}=\mathrm{C}, \mathrm{Ar}) ;{ }^{1} \mathrm{H}-\mathrm{NMR}(\delta \mathrm{ppm})\left(\mathrm{CD}_{3} \mathrm{OD}\right)$ : $7.83\left(\mathrm{~d}, 1 \mathrm{H}, J_{\mathrm{m}}=1.5 \mathrm{~Hz}, \operatorname{ArH}, \mathrm{C}-4\right), 6.88(\mathrm{dd}, 2 \mathrm{H}$, $\left.J_{\mathrm{o}}=7.9 \mathrm{~Hz}, J_{\mathrm{m}}=1.5 \mathrm{~Hz}, A \mathrm{ArH}, \mathrm{C}-6\right), 6.80\left(\mathrm{~d}, 1 \mathrm{H}, J_{\mathrm{o}}=\right.$ $7.9 \mathrm{~Hz}, \quad \mathrm{ArH}, \quad \mathrm{C}-7) ;{ }^{13} \mathrm{C}-\mathrm{NMR}(\delta \mathrm{ppm})\left(\mathrm{CD}_{3} \mathrm{OD}\right)$ :
$186.75(\mathrm{Q} \overline{\mathrm{C}} \mathrm{C}), \quad 157.43(\mathrm{O}=\mathrm{C}$, lactam $), \quad 138.21$, 137.39, $133.81,130.8 \mathrm{Br}^{123.25} \& 119.29$ Qromatic carbons).

4: $\mathrm{IR}\left(\mathrm{KBr}, \mathrm{C}^{1}\right.$ ): 3080 (s, C-H, Ar), 2944, 2 (s, C-H, Aphatic), 1768 (s, C=O lactam 1674 (s, $\mathrm{C}=\mathrm{O}$ ), $16 \mathbf{1}$ ( $\mathrm{s}, \mathrm{C}=\mathrm{O}$, amide), 1558, $1482 \mathbf{Y}=\mathrm{C}, \mathrm{Ar}$ ), 128 (C-N); ${ }^{1} \mathrm{H}-\mathrm{NMR}$ ( $\left.8 \mathrm{ppm}\right)\left(\mathrm{C}_{3} \mathrm{OD}\right): 7.83-7.21$ $(\mathrm{m}, 4 \mathrm{H}, \mathrm{ArH}), 2.35\left(\mathrm{~s}, 3 \mathrm{H}, \mathrm{COCH}_{3}\right) ;{ }^{13} \mathrm{C}-\mathrm{NMR}(\delta$ ppm) $\left(\mathrm{CD}_{3} \mathrm{OD}\right): 187.56(\mathrm{O}=\mathrm{C}), 168.69\left(\mathrm{O}=\mathrm{C}-\mathrm{CH}_{3}\right)$,

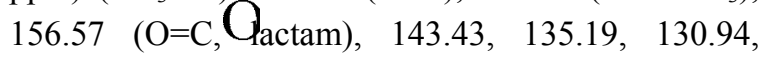
127.53, 122.27, 118.9 (anlomatic carbons), 15.42 $\left(\mathrm{CH}_{3}\right)$.

$\mathrm{Cl}$

5: IR (KBr, c-1 ${ }^{-1}$ ): 3072 (s, C-H, Ar), 2965, 2874 (s, C-H, aliphatic), 1758 (s, $\mathrm{C}=\mathrm{O}$ lactam), 1684 (s, $\mathrm{C}=\mathrm{O}), 1625(\mathrm{~s}, \mathrm{C}=\mathrm{O}, \mathrm{Amte}, 1558,1482(\mathrm{C}=\mathrm{C}, \mathrm{Ar})$, $1243(\mathrm{C}-\mathrm{N}) ;{ }^{1} \mathrm{H}-\mathrm{NMR}(\mathrm{\delta ppm})\left(\mathrm{DMSO}_{\mathrm{d}}\right)$ : $7.82(\mathrm{~d}$, $\left.1 \mathrm{H}, J_{\mathrm{m}}=1.6 \mathrm{fz}, \mathrm{ArH}, \mathrm{C}-4\right), 7.64\left(\mathrm{dd}, 1 \mathrm{H}, J_{\mathrm{o}}=7.6 \mathrm{~Hz}\right.$, $\left.J_{\mathrm{m}}=1.6 \mathrm{~Hz} \mathrm{ArH}, \mathrm{C}-6\right), 7.82\left(\mathrm{~d}, 1 \mathrm{H}, J_{\mathrm{o}}=7.6 \mathrm{~Hz}, \mathrm{ArH}, \mathrm{C}-\right.$ 7), 2.41 (s, $\left.3 \mathrm{H}, \mathrm{COCH}_{3}\right) ;{ }^{13} \mathrm{C}-\mathrm{NMR}$ ( $\left.\delta \mathrm{ppm}\right)$ (DMSO6.) $188 . \mathrm{dg}(\mathrm{O}=\mathrm{C}), 169.9 \mathrm{CHAN}-\mathrm{CH}_{3} \mathrm{O} 54.64(\mathrm{O}=\mathrm{C}$,
$\mathrm{O}$

$\mathrm{NH}$ $\mathrm{N}$ $\mathrm{NHCOCH}$ 8 
lactam), 141.38, 133.19, 131.94, 128.53, 120.26, 117.98 (aromatic carbons), $14.42\left(\mathrm{CH}_{3}\right)$.

6: IR ( $\left.\mathrm{KBr}, \mathrm{cm}^{-1}\right)$ : 3112 (s, C-H, Ar), 2960, 2870 (s, C-H, aliphatic), 1755 (s, C=O lactam), 1697 (s, $\mathrm{C}=\mathrm{O}), 1645$ (s, $\mathrm{C}=\mathrm{O}$, amide), 1548, $1482(\mathrm{C}=\mathrm{C}, \mathrm{Ar})$, $1232(\mathrm{C}-\mathrm{N}) ;{ }^{1} \mathrm{H}-\mathrm{NMR}(\delta \mathrm{ppm})\left(\mathrm{DMSO}_{\mathrm{d}}\right): 7.61$ (d, $\left.1 \mathrm{H}, J_{\mathrm{m}}=1.7 \mathrm{~Hz}, \mathrm{ArH}, \mathrm{C}-4\right), 7.56\left(\mathrm{dd}, 1 \mathrm{H}, J_{\mathrm{o}}=8.3 \mathrm{~Hz}\right.$, $\left.J_{\mathrm{m}}=1.7 \mathrm{~Hz} \mathrm{ArH}, \mathrm{C}-6\right), 7.82\left(\mathrm{~d}, 1 \mathrm{H}, J_{\mathrm{o}}=8.3 \mathrm{~Hz}, \mathrm{ArH}, \mathrm{C}-\right.$ 7); ${ }^{13} \mathrm{C}-\mathrm{NMR}$ ( $\left.\delta \mathrm{ppm}\right)\left(\mathrm{DMSO}-\mathrm{d}_{6}\right): 186.56(\mathrm{O}=\mathrm{C})$, $168.67\left(\mathrm{O}=\underline{\mathrm{C}}-\mathrm{CH}_{3}\right), 157.39(\mathrm{O}=\mathrm{C}$, lactam $), 140.85$, $134.11,131.46,127.39,121.63,118.21$ (aromatic carbons), $15.26\left(\mathrm{CH}_{3}\right)$.

7: IR ( $\left.\mathrm{KBr}, \mathrm{cm}^{-1}\right)$ : 3421 (N-H, lactam), 3406 (s, N-H, amide), 2963, 2857 (s, C-H, aliphatic), 1717 (s, $\mathrm{C}=\mathrm{O}$, lactam), 1705 (s, $\mathrm{C}=\mathrm{O}$, amide), 1520, 1568 $(\mathrm{C}=\mathrm{C}, \mathrm{Ar}), 1231 \quad(\mathrm{C}-\mathrm{N}$, amide $) ;{ }^{1} \mathrm{H}-\mathrm{NMR} \quad(\delta \mathrm{ppm})$ (DMSO-d $\left.\mathrm{d}_{6}\right): 8.92(\mathrm{~s}, 1 \mathrm{H}$, lactam NH), $8.72(\mathrm{~s}, 1 \mathrm{H}$, amide NH), 7.51-6.93 (m, 4H, ArH), 4.02 (q, 2H, $J$ $=8 \mathrm{~Hz}, \mathrm{C}-6), 2.49\left(\mathrm{~s}, 3 \mathrm{H}, \mathrm{CH}_{3} \mathrm{CO}\right), 1.17(\mathrm{t}, J=8 \mathrm{~Hz}$, $2 \mathrm{H}, \mathrm{C}-5) ;{ }^{13} \mathrm{C}-\mathrm{NMR}(\delta \mathrm{ppm})\left(\mathrm{DMSO}-\mathrm{d}_{6}\right): 167.56(\mathrm{C}-$ 2), 164.28 ( $\mathrm{C}=\mathrm{O}$, amide), 155.54 (C-3), 143.86, 133.57, 129.81, 125.67, 122.38, 121.58 (aromatic carbons), 48.32 (C-5), 37.81 (C-6), $22.00\left(\mathrm{CH}_{3}\right)$.

8: IR $\left(\mathrm{KBr}, \mathrm{cm}^{-1}\right): 3350(\mathrm{~N}-\mathrm{H}$, lactam), $3320(\mathrm{~N}-$ H, amide), 3060 (s, C-H, Ar), 2963, 2874 (s, C-H, aliphatic), $1750(\mathrm{C}=\mathrm{O}$, lactam $), 1710(\mathrm{C}=\mathrm{O}$, amide $)$, $1635(\mathrm{C}=\mathrm{N}$, imine $), 1600,1500(\mathrm{C}=\mathrm{C}, \mathrm{Ar}), 1231(\mathrm{C}-$ $\mathrm{N}$ amide); ${ }^{1} \mathrm{H}-\mathrm{NMR}$ ( $\left.\delta \mathrm{ppm}\right)\left(\mathrm{CD}_{3} \mathrm{OD}\right)$ : amide, $\left.\mathrm{NH}\right)$, 11.85 (s, 1H, lactam NH), 7.34-6.50 (m, 3H, ArH), 4.02 (q, $2 \mathrm{H}, J=8.1 \mathrm{~Hz}, \mathrm{C}-6), 2.50$ (s, $3 \mathrm{H}, \mathrm{CH}_{3} \mathrm{CO}$ ), $1.20(\mathrm{t}, 2 \mathrm{H}, \quad J=10 \mathrm{~Hz}, \mathrm{C}-5) ;{ }^{13} \mathrm{C}-\mathrm{NMR} \quad(\delta \mathrm{ppm})$ $\left(\mathrm{CD}_{3} \mathrm{OD}\right): 168.45$ (C-2), $165.43 \quad(\mathrm{C}=\mathrm{O}$, amide), 156.24 (C-3), 146.32, 130.35, 129.23, 133.47, 123.89, 122.11 (aromatic carbons), 49.98 (C-5), $38.32(\mathrm{C}-6), 21.12\left(\mathrm{CH}_{3}\right)$.

9: $\mathrm{IR}\left(\mathrm{KBr}, \mathrm{cm}^{-1}\right): 3373(\mathrm{~N}-\mathrm{H}$, lactam), $3304(\mathrm{~N}-$ H, amide), 3110 (s, C-H, Ar), 2910, 2885 (s, C-H, aliphatic), 1780 (s, $\mathrm{C}=\mathrm{O}$, lactam), $1710(\mathrm{~s}, \mathrm{C}=\mathrm{O}$, amide), 1600, 1520 (C=C, Ar), 1131 (C-N amide); ${ }^{1} \mathrm{H}-\mathrm{NMR}(\delta \mathrm{ppm})\left(\mathrm{CD}_{3} \mathrm{OD}\right): 8.04\left(\mathrm{~d}, 1 \mathrm{H}, J_{\mathrm{o}}=8.1 \mathrm{~Hz}\right.$, ArH, C-6), $7.53\left(\mathrm{dd}, 1 \mathrm{H}, J_{\mathrm{o}}=8.1 \mathrm{~Hz}, J_{\mathrm{m}}=1.9 \mathrm{~Hz}, \mathrm{ArH}\right.$, C-5), $6.84\left(\mathrm{~d}, 1 \mathrm{H}, J_{\mathrm{o}}=8.1 \mathrm{~Hz}, \mathrm{ArH}, \mathrm{C}-3\right.$ ) $), 4.1(\mathrm{q}, 2 \mathrm{H}$, $J=8 \mathrm{~Hz}, \mathrm{C}-6), 2.66\left(\mathrm{~s}, 3 \mathrm{H}, \mathrm{CH}_{3} \mathrm{CO}\right), 2.56(\mathrm{t}, 2 \mathrm{H}$, $J=8 \mathrm{~Hz}, \mathrm{C}-5) ;{ }^{13} \mathrm{C}-\mathrm{NMR}(\delta \mathrm{ppm})\left(\mathrm{CD}_{3} \mathrm{OD}\right): 167.93$ (C-
2), 164.56 ( $\mathrm{C}=\mathrm{O}$, amide), 155.67 (C-3), 146.55, $130.24,131.15,128.35,122.65,122.16$ (aromatic carbons), 49.56 (C-5), 37.78 (C-6), $22.28\left(\mathrm{CH}_{3}\right)$.

10: IR ( $\left.\mathrm{KBr}, \mathrm{cm}^{-1}\right): 3410$ (N-H, lactam), 3070 (s, C-H, Ar), 2979, 2846 (s, C-H, aliphatic), 1683 (s, $\mathrm{C}=\mathrm{O}$, lactam), 1652 (s, $\mathrm{C}=\mathrm{O}$, amide), $1559(\mathrm{C}=\mathrm{C}$, Ar); ${ }^{1} \mathrm{H}-\mathrm{NMR}(\mathrm{\delta ppm})\left(\mathrm{CD}_{3} \mathrm{OD}\right): 7.92-6.95(\mathrm{~m}, 5 \mathrm{H}$, ArH), 2.9 (t, $2 \mathrm{H}, J=8.1 \mathrm{~Hz}, \mathrm{C}-7), 2.6$ (t, $2 \mathrm{H}, J=$ $8.1 \mathrm{~Hz}, \mathrm{C}-5), 1.30 \quad(\mathrm{~m}, \quad 2 \mathrm{H}, \quad \mathrm{C}-6) ;{ }^{13} \mathrm{C} \quad-\mathrm{NMR}$ $\left(\mathrm{CD}_{3} \mathrm{OD}\right): 169.47 \quad(\mathrm{C}-2), 164.32 \quad(\mathrm{C}=\mathrm{O}$, amidal $)$, 155.96 (C-3), 144.18, 132.95, 133.16, 129.38, 122.85, 120.19 (aromatic carbons), 45.00 (C-5), 35.17 (C-7), 22.78 (C-6).

11: IR ( $\left.\mathrm{KBr}, \mathrm{cm}^{-1}\right)$ : 3415 (NH, amide), 3050 (s, C-H, Ar), 2964, 2875 (s, C-H, aliphatic), 1774, 1725 (s, $\mathrm{C}=\mathrm{O}$, amide), 1600, 1500, $(\mathrm{C}=\mathrm{C}, \mathrm{Ar}), 1130(\mathrm{C}-\mathrm{N}$, amide); ${ }^{1} \mathrm{H}-\mathrm{NMR}(\delta \mathrm{ppm})\left(\mathrm{CD}_{3} \mathrm{OD}\right): 7.62-7.34(\mathrm{~m}$, $8 \mathrm{H}, \mathrm{ArH}), 3.5\left(\mathrm{~m}, 6 \mathrm{H}, 3 \times \mathrm{CH}_{2}\right), 2.55\left(\mathrm{~s}, 3 \mathrm{H}, \mathrm{CH}_{3} \mathrm{CO}\right)$; ${ }^{13} \mathrm{C}-\mathrm{NMR} \quad(\delta \mathrm{ppm}) \quad\left(\mathrm{CD}_{3} \mathrm{OD}\right): 185.67 \quad(2 \times \mathrm{C}=\mathrm{O})$, $168.19(2 \times \mathrm{C}=\mathrm{O}$, amide $), 165.23(2 \times \mathrm{C}=\mathrm{O}), 140.23$

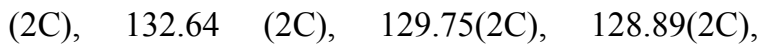
$127.12(2 \mathrm{C}), \quad 122.55(2 \mathrm{C})$ (12 aromatic carbons), $43.32,35.67,30.43\left(3 \times \mathrm{CH}_{2}\right)$

12: $\mathrm{IR}\left(\mathrm{KBr}, \mathrm{cm}^{-1}\right): 3114$ (s, C-H, Ar), 2964, 2875 (s, C-H, aliphatic), 1717 (s, C=O, lactam), 1705 (s, $\mathrm{C}=\mathrm{O}$, amide), $1665(\mathrm{w}, \mathrm{C}=\mathrm{N}), 1600,1500,(\mathrm{C}=\mathrm{C}$, $\mathrm{Ar}$, 1233 (C-N, amide); ${ }^{1} \mathrm{H}-\mathrm{NMR}\left(\mathrm{CDCl}_{3}\right)$ : 7.30-6.75 (m, 8H, ArH), 2.43 (s, 3H, $\left.\mathrm{CH}_{3} \mathrm{CO}\right) ;{ }^{13} \mathrm{C}-\mathrm{NMR}$ $\left(\mathrm{CDCl}_{3}\right): 168.21(\mathrm{C}=\mathrm{O}), 166.35(\mathrm{C}=\mathrm{N}), 156.93(\mathrm{C}=\mathrm{O}$ lactam), 153.12, 132.64, 131.32, 129.15, 128.43, 127.12, 122.55 (Aromatic Carbons), $15.47\left(\mathrm{CH}_{3} \mathrm{CO}\right)$.

Demonstration of cytotoxicity activity. The aliquots of 3 different concentrations level (50, 100 and $150 \mu \mathrm{g} / \mathrm{ml}$ ) of each of the test samples was prepared by dilution method. To get a $150 \mathrm{ppm}$ of such solutions $1.5 \mathrm{mg}$ of each of the compounds was dissolved in $10 \mathrm{ml}$ of dimethyl sulphoxide (DMSO). Further $100 \mathrm{ppm}$ and $50 \mathrm{ppm}$ were made from the $150 \mathrm{ppm}$ solutions by dilution method. Then $5 \mathrm{~mL}$ of each of the test sample of different concentrations were taken in different test tubes and 10-20 brine shrimp nauplii (was used as test animal for anticancer activity investigation and its scientific name is Artemia Salina $)^{10}$ immediately transfer to the 
solutions. After 1, 2 and 3 hours, the test tubes were observed and the numbers of survived nauplii in each test tube were counted to get a representative $\mathrm{LD}_{50}$. The initial toxicity test is $\mathrm{LD}_{50}$ (Lethal dose for $50 \%$ of a group of animal) in which the various doses of the test samples ranges from 0 to $100 \%$ lethality are given to Brine shrimps. The mortality of Brine shrimps having a fixed concentration of the compounds is in a fixed period of time (approximately two days). The $\mathrm{LD}_{50}$ of an agent is the dose that kill $50 \%$ of the test animals, is determined experimentally. $\mathrm{LD}_{50}$ is inversely proportional to the toxicity of the compound. The toxicity of a chemical is determined at several doses. In other words, the $\mathrm{LD}_{50}$ is the concentration of the drug to the $50 \%$ mortality of the population. From this, the percentage of lethality of brine shrimp nauplii was obtained at each concentration for each sample. An approximate linear correlation was observed when logarithm of concentration was plotted against percentage of mortality and the values of $\mathrm{LD}_{50}$ were calculated from the graphs.
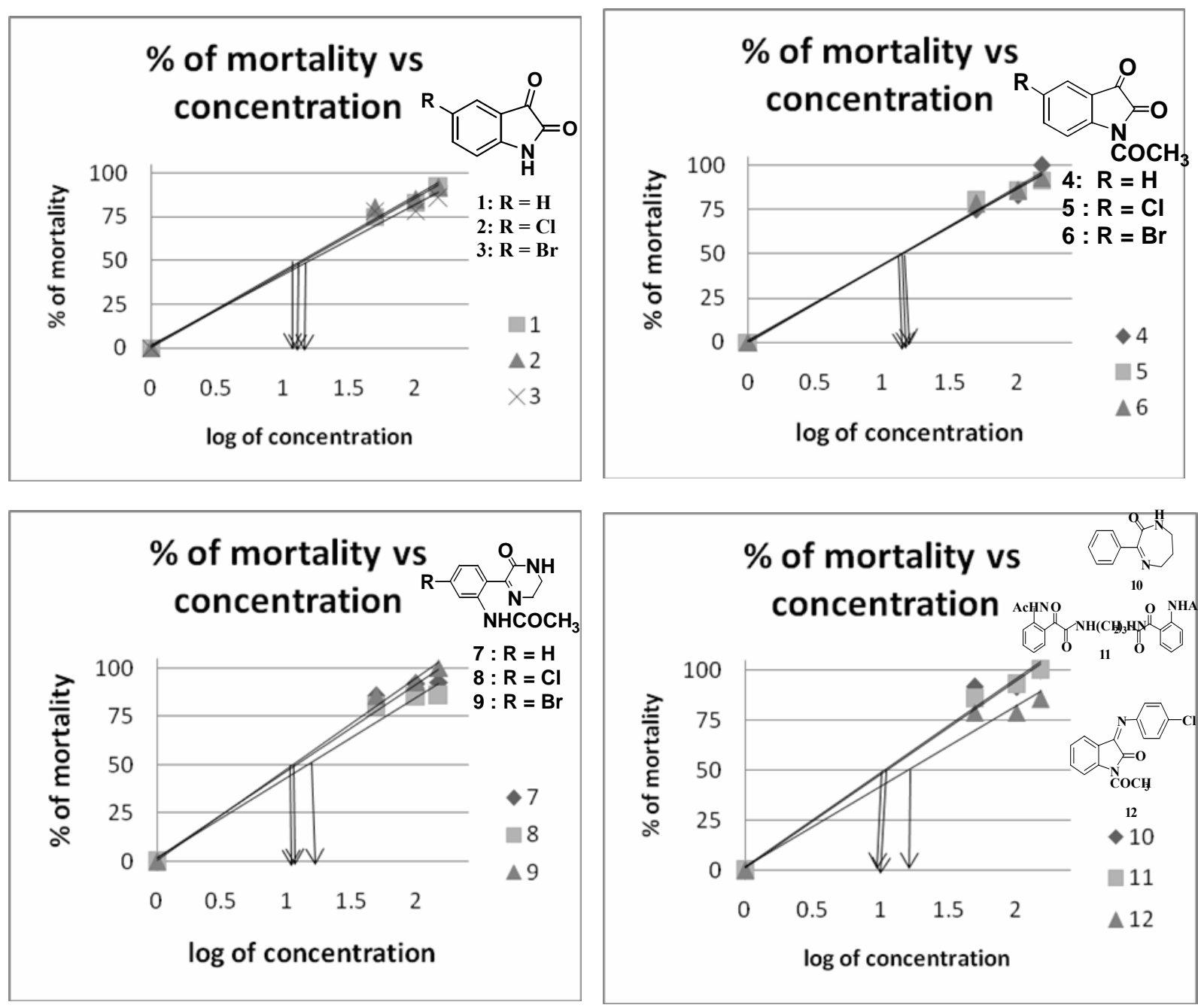


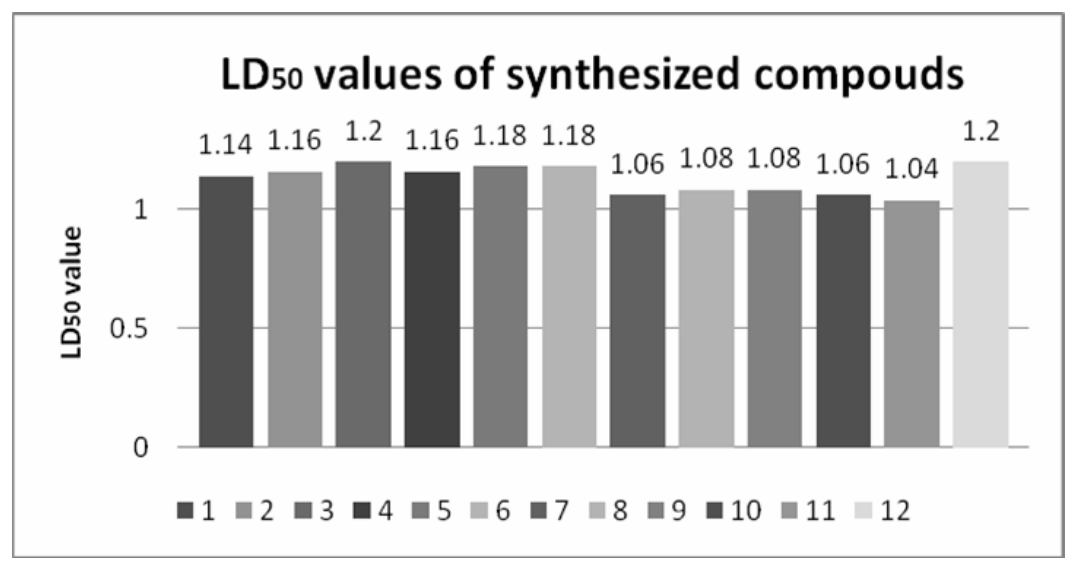

\section{RESULTS AND DISCUSSION}

The cytotoxicity of the synthesized compounds was investigated through brine shrimp lethality bioassay. All the synthesized compounds showed adequate cytotoxic effect. The present study stressed mainly on two important factors. Of these one is to the synthesis of heterocycles having $\beta$-lactam arrangement and the other one is to determine their cytotoxicity. Nitrogenous heterocyclic organic compounds having extra keto group shows biological activity. ${ }^{8}$ The synthetic route of the compounds (112) is mainly based on the substitution, ring cleavage and consequent ring expansion reactions. Hence the synthetic pathway facilitated to introduce further $\mathrm{N}$ atom in the ring system to provide diazo-biphenyls with $\mathrm{C}=\mathrm{O}$ moieties. Furthermore, each of the compounds contains a high percentage of nitrogen. Therefore, it might have enhanced the cytotoxicy effect. The screening of the synthesized compounds through Structure Activity Relationship (SAR) showed that different indoxyls such as isatins 1-3 are not so pronounced in their activity. But the $N$-acetyl derivatives (4-6) showed upward tendency of cytotoxic potency. The cleavage of the lactam moieties and the consequent cyclization provided with diazo-biphenyls, (7-10) showed good cytotoxicity. These results clearly indicate that lactam arrangement with additional nitrogen atom in the ring system enhanced cytotoxicity remarkably. Heterocyclic systems with halogen substituted pattern ( $\mathrm{Cl}$ - or $\mathrm{Br}$-) show greater propensity of action. Even
$N$-acetylated isatins with the substitution of bromine/chlorine in compound $\mathbf{5}$ and $\mathbf{6}$ were highly active than the un-substituted compounds. Same result has also been reflected in case of diazobiphenyl chloro-substituted compound 7 and bromosubstituted compound $\mathbf{8}$, showed good cytotoxicity.

\section{CONCLUSION}

In conclusion we have described a simple, rapid and facile synthetic route to oxindoles and diazobiphenyls, potential model compounds for chemical and pharmaceutical studies. The purpose of the synthesis of such heterocyclic compounds was to determine cytotoxicity against brine shrimp. From the results it can be stated that structural modification of molecules led to alteration in bioactivity such as cytotoxicity. Increasing the number of nitrogen atom by the cleavage of the lactam moieties and consequent cyclization provided with diazobiphenyls (7-10), which exhibited good cytotoxicity. These results clearly indicate that lactam arrangement with additional nitrogen atom in the ring system enhanced the cytotoxicity. In addition, substitution with halogen in the aromatic system resulted in different compounds 5-10 with greater cytotoxicity.

\section{REFERENCES}

1. Smith, J. and Stein, V. 2009. A development of a database analysis that provides putative metabolic enzyme reactions for ligand-based drug design. Comput. Biol. Chem. 33, 149159. 
2. Eline, M.M., Almeida, F.V., John, S.G, Pinto, A.C. and Fernandes, P.D. 2007. Isatins inhibit cyclooxygenase-2 and inducible nitric oxide synthase in a mouse macrophage cell line. Eur. J. Pharmacol. 5, 200-206.

3. Giselle, C. and Ferreira, A. 2006. Oxindoles and copper complexes with oxindole derivatives as potential pharmacological agents. J. Braz. Chem. Soc. 17, 1-22.

4. Hossain, M.M., Islam, N., Khan, R. and Islam, M.R. 2007. Cytotoxicity study of dimethylisatin and its heterocyclic derivatives. Bangladesh J. Pharmacol. 2, 66-70.

5. Islam, M.R., Abedin, J. and Khayer, K. 2001. Synthesis of some 5-spiro-(5'-methylisatin)-4- $N$-acetyl-2-acetylamino- $\Delta^{2}$ 1,3,4-thiadiazoline and 5-spiro-(5'-methylisatin)-4-N-acetyl2-(5-methylisatin-3-hydrazino)- $\Delta^{2}$-1,3, 4-thiadiazolines. Ind. J. Chem. 40B, 240-247.

6. Islam, M.R., Abedin, J., Hossain, M.M. and Duddeck, H. 1998. Synthesis of 1-methyl bis-dioxo-pyrrolino$\left[2^{\prime}, 3^{\prime}: 2,3 ; 2^{\prime \prime}, 33^{\prime \prime}: 6,5\right]$ benzene and its heterocycles via thiocarbohydrazone, thiosemicarbazone. J. Bangladesh Chem. Soc. 11, 71-78.
7. Salvam, P., Murugesh, N., Chandramohan, M. and Clereq, D.E. 2004. Pharmacological evaluation of some novel isatin derivatives. Ind. J. Pharm. Sci. 66, 465-468.

8. Islam, M.R. and Mohsin, M. 2007. Synthesis of isatin, 5chloroisatin and their $\Delta^{2}-1,3,4$-oxadiazoline derivatives for comparative cytotoxicity study on brine shrimp. Bangladesh J. Pharmacol. 2, 7-12.

9. Binta, N. and Islam, M.R. 2007. Cytotoxicity study of pyrazole derivatives. Bangladesh J. Pharmacol. 2, 81-87.

10. Solis, P.N., Wright, C.W., Anderson, M.M., Gupta M.P., and Phillipson, J.D. 1997. A microwell cytotoxicity assays using Artima Salina (brine shrimp). Planta Med. 59, 250-252. 